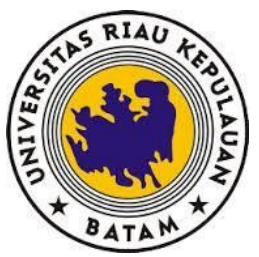

Available online at www.journal.unrika.ac.id

Jurnal KOPASTA

Jurnal KOPASTA, 6 (2),(2019) 64- 74

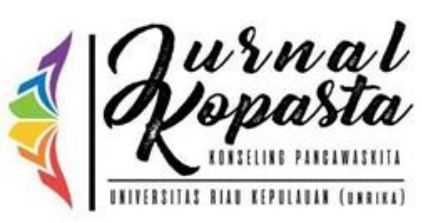

\title{
PENGARUH LAYANAN INFORMASI DALAM UPAYA MENINGKATKAN PEMAHAMAN TENTANG HIV/AIDS BAGI SISWA SMA SRIGUNA PALEMBANG
}

\section{INFLUENCE OF INFORMATION SERVICES IN EFFORTS TO INCREASE UNDERSTANDING OF HIV / AIDS FOR SRIGUNA PALEMBANG HIGH SCHOOL STUDENTS}

\author{
Aris Siswanto $^{1}$ \\ ${ }^{1}$ (Program Studi Bimbingan dan Konseling, FKIP Universitas PGRI Palembang, Indonesia \\ 'e-mail: siswantoooo@yahoo.com
}

\begin{abstract}
Abstrak
United Nations Programme on HIV/AIDS (UNAIDS) melaporkan jumlah orang hidup dengan HIV pada tahun 2012 sebanyak 35,3 juta orang. Pada tahun yang sama angka kematian AIDS sebesar 1,6 juta orang dan sebanyak 2,3 juta orang baru terinveksi HIV. Melihat tingginya angka penderita HIV/AIDS, menjadi tugas pemerintah untuk terus mensosialisasikan tentang HIV/AIDS. Di sekolah, guru bimbingan dan konseling memberikan peranan penting untuk memberikan informasi tentang penyakit ini, khususnya para pelajar SMA. Pada masa ini kelompok remaja dalam rentan usia 10-19 tahun merupakan periode terjadinya pertumbuhan dan perkembangan pesat baik fisik, psikologis maupun intelektual. Berdasarkan hasil penelitian di lapangan, banyak siswa yang tidak memahami tentang HIV/AIDS. Salah satu cara dalam mengatasi masalah tersebut adalah dengan memberikan layanan informasi. Tujuan penelitian ini adalah untuk mengetahui apakah terdapat pengaruh layanan informasi dalam upaya meningkatkan pemahaman tentang HIV/AIDS bagi siswa. Penelitian ini menggunakan metode kuantitatif dengan quasi experimental design. Subjek penelitian ini adalah siswa SMA Sriguna Palembang kelas XI IPA 2. Instrument penelitian menggunakan model skala likert, selanjutnya dianalisis menggunakan uji-t. Secara umum, penelitian ini menunjukan adanya pengaruh layanan informasi dalam upaya meningkatkan pemahaman tentang HIV/AIDS. Berdasarkan hasil penelitian yang telah didapat, diharapkan kerjasama berbagai pihak terkait dalam upaya meningkatkan pemahaman siswa.
\end{abstract}

Kata Kunci: Layanan Informasi, HIV/AIDS

\begin{abstract}
The United Nations Programme on HIV/AIDS (UNAIDS) reports the number of people living with HIV in 2012 as much as 35.3 million people. In the same year AIDS mortality rate amounted to 1.6 million people and as many as 2.3 million people have HIV. Seeing the high number of people with HIV/AIDS, it is the government's duty to continue socializing about HIV/AIDS. At school, tutoring and counseling teachers provide an important role to provide information about the disease, especially high school students. At this time a group of teenagers in susceptible to age 10-19 years is a period of rapid growth and development both physical, psychological and intellectual. Based on the results of the research in the field, many students do not understand about HIV/AIDS. One way of addressing the problem is to provide information services. The purpose of this research is to find out if there is an influence on information services in an effort to improve understanding of HIV/AIDS for students. This research uses quantitative methods with quasi experimental design. The subject of this research is high school student Sriguna Palembang XI IPA 2. The research Instrument uses a Likert scale model, subsequently analysed using Test-T. In general, this research shows the influence of information services in the effort to improve understanding of HIV/AIDS. Based on the results of the research that has been obtained, the cooperation of various parties is expected to improve students ' understanding.
\end{abstract}

Keywords: Information Services, HIV/AIDS 


\section{PENDAHULUAN}

AIDS adalah penyakit seksual berbahaya yang perkembangannya menjadi masalah di dunia karena penyakit ini belum ditemukan obatnya. AIDS merupakan penyakit yang dapat ditularkan melalui hubungan seksual atau melalui jarum suntik. Penyakit ini sering dikaitkan dengan kesehatan reproduksi. AIDS atau dalam bahasa ilmiahnya Acquired Immunodeficiency Syndrome adalah penyakit yang timbul karena rusaknya sistem kekebalan tubuh akibat infeksi dari virus HIV atau dalam bahasa ilmiahnya Human Immunodeficiency Virus dimana virus ini menyerang sistem kekebalan tubuh manusia.

AIDS pada umumnya ditularkan melalui kontak langsung bagian lapisan kulit dalam (Membran Mukosa) atau aliran darah dengan cairan tubuh yang telah terinfeksi virus HIV seperti darah, air mani, cairan vagina bahkan ASI (Air Susu Ibu). Penularan virus ini dapat melalui hubungan seksual baik vaginal, anal, ataupun oral, transfusi darah, jarum suntik yang terkontaminasi, serta kontak fisik lainnya dengan cairan yang telah terinfeksi virus, bahkan bayipun bisa terkena penyakit AIDS karena proses kehamilan atau menyusui.

United Nations Programme on HIV/AIDS (UNAIDS) melaporkan jumlah orang hidup dengan HIV pada tahun 2012 sebanyak 35,3 juta orang. Pada tahun yang sama angka kematian AIDS sebesar 1,6 juta orang dan sebanyak 2,3 juta orang baru terinveksi HIV. Penyakit HIV/AIDS sangat berbahaya karena tidak saja membawa dampak buruk bagi kesehatan manusia namun juga negara. Tingginya angka kumulatif HIV di Indonesia, sampai desember 2013 tercatat sebanyak 127.416 kasus dan jumlah kumulatif kasus AIDS sampai tahun 2013 sebanyak 52.348 kasus dimana tercatat sebagai pasien baru diatas 2,6 juta, serta 1,8 juta diantaranya mengalami kematian setiap tahunnya dan secara global usia remaja berkisar 10-19 tahun merupakan usia rentan terinfeksi HIV/AIDS. Takainginan, Pesak, dkk (2016:1)

Melihat tingginya angka penderita HIV/AIDS, menjadi tugas pemerintah untuk terus mensosialisasikan tentang HIV/AIDS. Di sekolah, guru bimbingan dan konseling memiliki peranan penting untuk memberikan informasi tentang penyakit ini, khususnya para pelajar SMA. Pada masa ini kelompok remaja dalam rentan usia 10-19 tahun merupakan periode terjadinya pertumbuhan dan perkembangan pesat baik fisik, psikologis maupun intelektual. Salah satunya dengan memberikan layanan informasi.

Menurut Nursalim (2002:22) dalam Jurnal Listianah dan Muhari (2013:160) Layanan Informasi adalah kegiatan bimbingan yang bermaksud membantu siswa untuk 
mengenal lingkungannya. Tujuan layanan informasi ini untuk membekali individu dengan berbagai hal yang berguna untuk mengenal diri, merencanakan dan mengembangkan pola kehidupan sebagai pelajar, anggota keluarga dan masyarakat. Pemahaman yang diperoleh melalui layanan informasi digunakan sebagai bahan acuan dalam meningkatkan kegiatan dan prestasi belajar, mengembangkan cita-cita, menyelenggarakan kehidupan sehari-hari dan mengambil keputusan.

Perlu pemahaman tentang perilaku seksual pada remaja sebab masa remaja merupakan masa peralihan dari perilaku seksual anak-anak menjadi perilaku seksual dewasa. Kurangnya pemahaman tentang perilaku seksual pada remaja dapat menjadi pemicu terjangkitnya penyakit AIDS dimana dapat disebabkan karena banyak remaja yang sudah melakukukan seks beresiko. Pemahaman tentang perilaku seksual pada remaja dapat diberikan oleh guru disekolah dalam hal ini bisa menjadi tanggung jawab guru bimbingan dan konseling.

Berdasarkan observasi yang telah sebelumnya peneliti lakukan, banyak remaja di Palembang khususnya daerah Plaju kurang memahami tentang prilaku seksual itu sendiri, bahkan untuk kasus HIV/AIDS remaja hanya sebatas mengetahui bahwa itu merupakan penyakit seksual berbahaya karena penderitanya merupakan seorang yang suka melakukan hubungan seksual beresiko dan beranggapan bahwa penderitanya harus dijauhi. Remaja tidak memahami secara mendalam tentang HIV/AIDS itu sendiri.

Melalui sekolah siswa mulai belajar dan menimba ilmu. Pendidikan tentang seksualpun sudah sewajarnya didapatkan dari sekolah dan tidak lagi menjadi hal yang tabu. Perlu adanya penyuluhan tentang kesehatan seksual kepada remaja khususnya siswa SMA. Hal ini bertujuan untuk memberi pemahaman dan menambah wawasan remaja tentang kesehatan seksual, HIV/AIDS dan pencegahannya.

Berdasarkan fenomena yang terjadi saat ini dan melihat tingginya resiko remaja terinfeksi virus HIV/AIDS membuat peneliti tergerak untuk memberikan layanan informasi sebagai upaya memberikan pemahaman tentang HIV/AIDS bagi remaja dimana pada penelitian ini yang menjadi objek adalah siswa SMA, khususnya SMA Sriguna Palembang.

\section{METODOLOGI}

Jenis penelitian yang digunakan dalam penelitian ini adalah penelitian kuantitatif. Metode yang digunakan dalam penelitian ini adalah metode eksperimen dalam bentuk desain eksperimennya yaitu Pre-Eksperimental Design. Bentuk penelitian Pre- 
Eksperimental Design yang digunakan adalah One-Group Pretest-Posttest. Subjek dalam penelitian ini sebanyak 31 siswa. Instrumen yang digunakan dalam penelitian ini berbentuk skala model Likert. Instrumen penelitian menunjukan tingkat validitas instrumen sebesar 0,444 dan reliabilitas dengan nilai Alpha Cronbach sebesar 0,912. Data yang telah terkumpul dianalisis dengan cara menghitung skor rata-rata pemahaman tentang HIV/AIDS yang kemudian di deskripsikan menggunakan norma pengkatagorian sebagai berikut:

Tabel 1. Katagorisasi penskoran

\begin{tabular}{|c|c|c|c|}
\hline NO & Skor & $\mathbf{\%}$ & Kategori \\
\hline 1 & $\geq 112$ & $\geq 83$ & $\begin{array}{c}\text { Sangat } \\
\text { Tinggi }\end{array}$ \\
\hline 2 & $105-111$ & $78-82$ & Tinggi \\
\hline 3 & $98-104$ & $72-77$ & Sedang \\
\hline 4 & $91-97$ & $67-71$ & Rendah \\
\hline 5 & $84-90$ & $62-66$ & $\begin{array}{c}\text { Sangat } \\
\text { Rendah }\end{array}$ \\
\hline
\end{tabular}

Data yang diperoleh selanjutnya dianalisis menggunakan uji-t.

\section{HASIL DAN PEMBAHASAN}

\section{Deskripsi Data}

\section{Data Pretest}

Sesuai dengan dilakukannya Pretest, gambaran awal mengenai pemahaman HIV/AIDS sebelum diberikan perlakuan. Berikut disajikan gambaran awal Pretest pemahaman HIV/AIDS sebagai berikut:

Tabel 2. Distribusi Frekuensi Pemahaman Tentang HIV/AIDS

\begin{tabular}{|c|c|c|c|c|}
\hline NO & Interval & Kategori & Frekuensi & $\%$ \\
\hline 1 & $\geq 112$ & $\begin{array}{c}\text { Sangat } \\
\text { Tinggi }\end{array}$ & 1 & $3 \%$ \\
\hline 2 & $105-111$ & Tinggi & 5 & $16 \%$ \\
\hline 3 & $98-104$ & Sedang & 8 & $26 \%$ \\
\hline 4 & $91-97$ & Rendah & 8 & $26 \%$ \\
\hline 5 & $84-90$ & $\begin{array}{c}\text { Sangat } \\
\text { Rendah }\end{array}$ & 9 & $29 \%$ \\
\hline & Jumlah & & $\mathbf{3 1}$ & $\mathbf{1 0 0}$ \\
\hline
\end{tabular}


Berdasarkan tabel diatas, hasil Pretest dari 31 orang siswa dapat disimpulkan bahwa yang memiliki pemahaman tentang HIV/AIDS berada dalam katagori "Sangat Rendah" dengan frekuensi 9 orang siswa.

\section{Data Posttest}

Sesuai dengan dilakukannya Posttest, gambaran awal mengenai pemahaman HIV/AIDS sebelum diberikan perlakuan. Berikut disajikan gambaran awal Pretest pemahaman HIV/AIDS sebagai berikut:

Tabel 3. Distribusi Frekuensi Pemahaman Tentang HIV/AIDS

\begin{tabular}{|c|c|c|c|c|}
\hline NO & Interval & Kategori & Frekuensi & $\%$ \\
\hline 1 & $\geq 112$ & Sangat Tinggi & 12 & $39 \%$ \\
\hline 2 & $105-111$ & Tinggi & 15 & $49 \%$ \\
\hline 3 & $98-104$ & Sedang & 2 & $6 \%$ \\
\hline 4 & $91-97$ & Rendah & 1 & $3 \%$ \\
\hline 5 & $84-90$ & Sangat Rendah & 1 & $3 \%$ \\
\hline \multicolumn{2}{|c|}{ Jumlah } & & $\mathbf{3 1}$ & $\mathbf{1 0 0} \%$ \\
\hline
\end{tabular}

Berdasarkan tabel diatas, dapat dilihat bahwa persentase tertinggi adalah $49 \%$ masuk dalam katagori "Tinggi” dengan frekuensi sebanyak 15 orang siswa dan persentase terendah adalah 3\% masuk dalam katagori "Sangat Rendah" dengan frekuensi sebanyak 1 orang siswa. Berdasarkan hasil tersebut dapat disimpulkan bahwa adanya pengaruhlayanan infprmasi dalam meningkatkan pemahaman tentang HIV/AIDS bagi siswa, khususnya siswa SMA Sriguna Palembang.

\section{Hasil Pretest dan Posttest Pemahaman tentang HIV/AIDS}

Data yang diperoleh dari jawaban angket pretest dan Posttest selanjutnya dianalisis untuk diketahui perbandingan sebelum dan sesudah diberikan layanan/treatment dalam upaya meningkatkan pemahaman siswa tentang HIV/AIDS dengan menggunakan rumus uji-t sebagai berikut:

Tabel 4. Hasil Pretest dan Posttest Pemahaman tentang HIV/AIDS

\begin{tabular}{|c|c|c|c|c|}
\hline Resp & Pretest & Posttest & $\begin{array}{c}\text { Gain (d) } \\
\text { (Pretest } \\
\text { Posttest) }\end{array}$ & $\begin{array}{c}\text { Gain (d) } \\
\text { (Pretest }^{\text {Posttest) }} \mathbf{~}^{2}\end{array}$ \\
\hline 1 & 101 & 110 & 9 & 81 \\
\hline 2 & 90 & 97 & 7 & 49 \\
\hline 3 & 104 & 110 & 6 & 36 \\
\hline 4 & 99 & 109 & 10 & 100 \\
\hline 5 & 109 & 113 & 4 & 16 \\
\hline
\end{tabular}




\begin{tabular}{|c|c|c|c|c|}
\hline 6 & 105 & 124 & 19 & 361 \\
\hline 7 & 91 & 111 & 20 & 400 \\
\hline 8 & 96 & 107 & 11 & 121 \\
\hline 9 & 103 & 113 & 10 & 100 \\
\hline 10 & 92 & 101 & 9 & 81 \\
\hline 11 & 103 & 118 & 15 & 225 \\
\hline 12 & 106 & 109 & 3 & 9 \\
\hline 13 & 97 & 116 & 19 & 361 \\
\hline 14 & 93 & 112 & 19 & 361 \\
\hline 15 & 109 & 110 & 1 & 1 \\
\hline 16 & 87 & 89 & 2 & 4 \\
\hline 17 & 98 & 118 & 10 & 100 \\
\hline 18 & 94 & 108 & 14 & 196 \\
\hline 19 & 90 & 106 & 16 & 256 \\
\hline 20 & 107 & 108 & 1 & 1 \\
\hline 21 & 88 & 109 & 21 & 441 \\
\hline 22 & 117 & 124 & 7 & 49 \\
\hline 23 & 90 & 113 & 23 & 529 \\
\hline 24 & 97 & 111 & 14 & 196 \\
\hline 25 & 86 & 112 & 26 & 676 \\
\hline 26 & 88 & 119 & 31 & 961 \\
\hline 27 & 84 & 101 & 17 & 289 \\
\hline 28 & 93 & 108 & 15 & 225 \\
\hline 29 & 102 & 116 & 14 & 196 \\
\hline 30 & 98 & 109 & 11 & 121 \\
\hline 31 & 86 & 107 & 21 & 441 \\
\hline $\begin{array}{c}\text { Jumlah } \\
\sum\end{array}$ & 3003 & 3418 & 405 & 6983 \\
\hline
\end{tabular}

1) Dari perbedaan Pretest dan posttest

$$
M d=\frac{\sum d}{n}=\frac{405}{31}=13,06
$$

2) Jumlah kuadrat deviasi

$$
\begin{aligned}
& \sum x^{2} d=\sum d^{2}-\frac{\left(\sum d\right)^{2}}{n} \\
& =6983-\frac{405^{2}}{31} \\
& =6983-\frac{164025}{31}
\end{aligned}
$$


$=6983-5291,129=1691,871$

Untuk uji signifikan maka digunakan rumus uji-t sebagai berikut:

$t=\frac{M d}{\sqrt{\frac{\sum x^{2} d}{n(n-1)}}}$

$t=\frac{13,06}{\sqrt{\frac{1691,871}{31(31-1)}}}$

$t=\frac{13,06}{\sqrt{\frac{1691,871}{31(30)}}}$

$t=\frac{13,06}{\sqrt{\frac{1691,871}{930}}}$

$t=\frac{13,06}{\sqrt{1,819}}$

$t=\frac{13,06}{1,348}$

$t=9,68$

Berdasarkan hasil nilai $\mathrm{t}_{\text {hitung }}$ diatas, selanjutnya dibandingkan dengan nilai $\mathrm{t}_{\text {tabel }}$. Untuk mendapatkan nilai $\mathrm{t}_{\text {tabel }}$ dengan $\mathrm{dk}=\mathrm{n}-1$ atau $\mathrm{dk}=31-1=30$ bila kesalahan ditetapkan.

\section{Uji Hipotesis}

Adapun kondisi pemahaman tentang HIV/AIDS sebelum dan sesudah diberika layanan informasi dapat dilihat pada gambar dibawah ini:

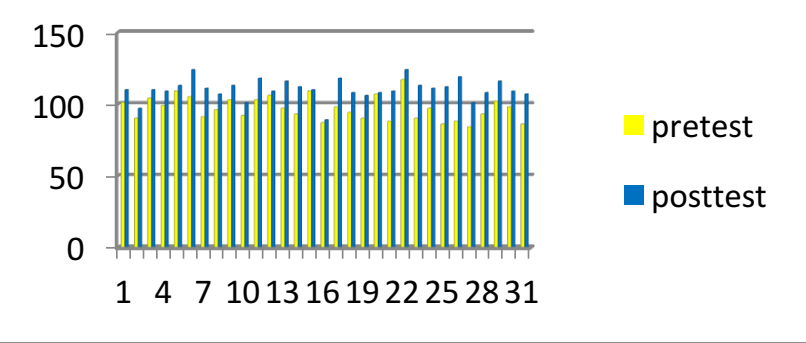

Gambar 1. Histogram hasil Pretest dan Posttest 
Berdasarkan gambar diatas, terlihat jelas terdapat perbedaan peningkatan setelah diberikannya layanan/treatment yang meningkatkan pemahaman siswa SMA Sriguna tentang HIV/AIDS.

\section{Pembahasan}

Secara umum layanan informasi bermaksud memberikan pemahaman kepada individu-individu yang berkepentingan tentang berbagai hal yang diperlukan untuk menjalani suatu tugas atau kegiatan, atau untuk menentukan arah suatu tujuan atau rencana yang dikehendaki. Dengan demikian, layanan informasi itu pertama-tama merupakan perwujudan dari fungsi pemahaman pelayanan bimbingan dan konseling. Lebih jauh, layanan informasi akan dapat menunjang pelaksanaan fungsi-fungsi bimbingan dan konseling lainnya dalam kaitan antara bahan-bahan informasi itu dengan permasalahan individu, menurut Prayitno dan Amti (2013:260)

Pramudi dan Firman (2016:2) layanan informasi merupakan layanan bimbingan dan konseling yang membantu siswa menerima dan memahami berbagai informasi diri, sosial, karier, dan pendidikan lanjutan. Menurut Prayitno (2014:50) layanan informasi berusaha memenuhi kekurangan akan informasi yang mereka perlukan. Dalam layanan ini, kepada peserta layanan disampaikan berbagai informasi. Informasi itu kemudian diolah dan digunakan oleh individu untuk kepentingan hidup dan perkembangannya. Layanan informasi diselenggarakan oleh konselor yang diikuti oleh seseotang atau lebih peserta. Sedangkan menurut Risaldy dan Idris (2015:35) layanan informasi dimaksudkan untuk memberikan wawasan dan pemahaman baik untuk anak maupun orang tua.

Menurut Sudikno, Simanungkalit, dkk (2010:146) Acquired Immunodeficiency Syndrome atau Acquired Immune Deficiency Syndrome (AIDS) adalah sekumpulan gejala dan infeksi yang timbul karena rusaknya sistem kekebalan tubuh manusia akibat infeksi virus HIV atau infeksi virus-virus lain yang mirip yang menyerang spesies lainnya (SIV, FIV, dan Iain-lain). Virusnya sendiri bernama Human Immunodeficiency Virus (atau 
disingkat HIV) yaitu virus yang memperlemah kekebalan pada tubuh manusia. Orang yang terkena virus ini akan menjadi rentan terhadap infeksi oportunistik ataupun mudah terkena tumor.

Human Immunodeficiency Virus (HIV) merupakan penyebab penyakit Acquired Immune Deficiency Syndrome (AIDS) dengan cara menyerang sel darah putih sehingga dapat merusak sistem kekebalan tubuh manusia. Kasus HIV/AIDS merupakan fenomena gunung es, dengan jumlah orang yang dilaporkan jauh lebih sedikit dari yang sebenarnya. Hal ini terlihat dari jumlah kasus AIDS yang dilaporkan setiap tahunnya sangat meningkat secara signifikan. Di seluruh dunia, setiap hari diperkirakan sekitar 2000 anak di bawah 15 tahun tertular HIV dan sekitar 1400 anak dibawah 15 tahun meninggal dunia, serta menginfeksi lebih dari 6000 orang berusia produktif. Purwaningsih dan Widayatun $(2008: 76)$

Virus HIV tidak menyebabkan kematian secara langsung pada penderitanya, akan tetapi adanya penurunan imunitas tubuh yang menyebabkan mudah terserangnya infeksi. Penyakit HIV yang semulanya bersifat akut dan mematikan berubah menjadi penyakit kronis yang bisa dikelola. Namun demikian, hidup dengan penyakit kronis menyisakan persoalan-persoalan lain yang memerlukan penyesuaian-penyesuaian baik secara fisik, psikologis, sosial dan spiritual. Ibrahim, Kurnia, dkk (2017:272)

Berdasarkan data angket pretest yang telah diperoleh pada lembar instrumen dikelas XI IPA 2 berjumlah 31 orang siswa. Menurut hasil deskripsi dan analisis hasil angket pemahaman tentang HIV/AIDS diperoleh hasil dengan kategori "Sangat Tinggi" dengan interval skor $\geq 112$ dengan jumlah 1 siswa dengan persentase 3\%, kategori "Tinggi" dengan interval skor 105 - 111 dengan jumlah 5 siswa dengan persentase $16 \%$, interval skor 98 - 104 dengan kategori "Sedang” dengan jumlah 8 siswa dengan persentase 26\%, dan interval skor 91 - 97 dengan kategori "Rendah" berjumlah 8 orang siswa dengan persentase $26 \%$ dan dalam interval skor 84 - 90 dengan kategori "Sangat Rendah" 
berjumlah 9 orang siswa dengan persentase 29\%. Maka dapat disimpulkan dari 31 sampel pretest dengan rata-rata $\mathbf{9 6 , 8 7}$ bahwa tingkat pemahaman tentang HIV/AIDS siswa di SMA Sriguna Palembang "Rendah".

Berdasarkan data angket hasil posttest yang telah diperoleh pada lembar instrumen dikelas XI IPA 2 berjumlah 31 orang diambil dari siswa pretest awal. Menurut hasil deskripsi dan analisis hasil angket kategori "Sangat Tinggi" dengan interval skor $\geq 112$ dengan jumlah 12 siswa dengan persentase 39\%, kategori "Tinggi” dengan interval skor 105 - 111 dengan jumlah 15 siswa dengan persentase 49\%, interval skor 98 - 104 dengan kategori "Sedang" dengan jumlah 2 siswa dengan persentase 6\%, dan interval skor 91 97 dengan kategori "Rendah" berjumlah 1 orang siswa dengan persentase 3\%. Dan dalam interval skor 84 - 90 dengan kategori "Sangat Rendah" berjumlah 1 orang siswa dengan persentase 3\%. Maka dapat disimpulkan dari 31 sampel posttest dengan rata-rata 110,26 bahwa tingkat pemahaman tentang HIV/AIDS siswa di SMA Sriguna Palembang "Tinggi".

\section{KESIMPULAN}

Berdasarkan hasil penelitian yang telah dilakukan, dapat ditarik kesimpulan bahwa pemberian layanan informasi efektif dalam membantu siswa meningkatkan pemahamannya. Artinya, layanan informasi sangat berpengaruh dalam meningkatkan pemahaman siswa tentang HIV/AIDS. Penelitian ini mengarahkan kepada kesadaran siswa bahwa memahami tentang HIV/AIDS itu penting agar siswa dapat menghindari halhal yang membuat siswa mendekati penyebab terjangkitnya penyakit ini. Penelitian ini juga diharapkan mampu merubah persepsi tentang penderita HIV/AIDS. HIV/AIDS bukan hanya menghancurkan hidup penderitanya, tetapi juga dapat merusak suatu bangsa.

\section{DAFTAR PUSTAKA}

Ibrahim. K, Kurnia. Y, dkk. 2017. Hubungan Antara Fatigue, Jumlah CD4, dan Kadar Hemoglobin PadaPasien yang Terinveksi HIV. JKP. 5 (3) 271-280. 
Pramudiastuti, N, K. \& Firman. 2016. Evektivitas Layanan Informasi Menggunakan Pendekatan Kontextual Teaching and Learning (CTL) dengan Prinsip Konstrukvisme Untuk Mengurangi Proktasinasi Akademik Siswa. Jurnal Ilmiah Konseling FIP UNP. 1-10.

Prayitno \& Amti. E. 2013. Dasar-Dasar Bimbingan dan Konseling. Jakarta: Rineka Cipta. Prayitno. 2014. Jenis Layanan dan Kegiatan Pendukung Konseling. Padang: Universitas Negeri Padang.

Purwaningsih. S, \& Widayatun. 2008. Perkembangan HIV dan AIDS di Indonesia:Tinjauan Sosio Demografis. Jurnal Kependudukan Indonesia. 3 (2) 7595.

Risaldy. S \& Idris. M. 2015. Bimbingan dan Konseling. Jakarta: Luxima.

Sudikno, Simanungkalit. B, dkk. 2011. Pengetahuan HIV dan AIDS Pada Remaja di Indonesia. Jurnal Kesehatan Reproduksi. 1 (3) 145-154. 